International Journal of Health Sciences
Available online at www.sciencescholar.us
Vol. 6 No. 1, April 2022, pages: 40-49
e-ISSN: 2550-696X, p-ISSN: 2550-6978
https://doi.org/10.53730/ijhs.v6n1.3145

\title{
Health Literacy Study on Approaching Forest and Boosting Immune System Strategy
}

\author{
(1) CrossMark \\ Tamaulina Br Sembiring a, Irma Rachmawati Maruf b, Catur Budi Susilo c, \\ A. Nururrochman Hidayatulloh ${ }^{d}$, B. M. A. S. Anaconda Bangkara ${ }^{e}$
}

Manuscript submitted: 9 July 2021, Manuscript revised: 3 November 2021, Accepted for publication: 22 December 2021

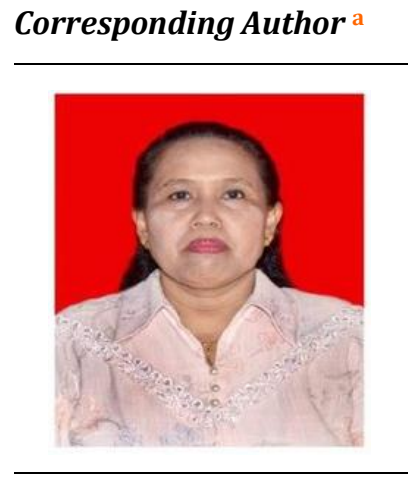

Keywords

boosting immune; community health center; COVID-19 pandemic; emotional health; health expert; health practitioner; healthy environment; healthy life; mental health;

\begin{abstract}
This study aimed to look further at the immunity possessed by humans who live in rural areas compared to urban areas. The method of this research is qualitative with the literature method, in which to answer this research, the researcher looks for evidence from various international journal publications published in the last ten years. Then, to prove the above assumption, the researcher first collects evidence of study findings that sound for health reasons, then chooses to live in a peaceful and pollution-free tree area. Next, we study and analyze in-depth evaluation and coding systems to draw conclusions that answer the above issues validly and convincingly. The findings of this study are that humans who live in forests have a robust immune system compared to those who live in cities, so when the COVID-19 pandemic occurs, it is not a problem. Suggestions for the findings of this study are expected to be meaningful input for the development of environmental health sciences in further studies, both for academics and environmental health practitioners.
\end{abstract}

International Journal of Health Sciences (C) 2022. This is an open access article under the CC BY-NC-ND license (https://creativecommons.org/licenses/by-nc-nd/4.0/).

\section{Contents}

Abstract

1 Introduction...

2 Materials and Methods

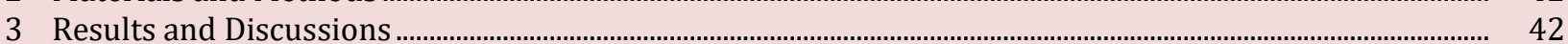

4 Conclusion.

\footnotetext{
a Universitas Pembangunan Panca Budi, Medan, Indonesia

${ }^{\text {b }}$ Universitas Pasundan, Bandung, Indonesia

c Politeknik Kesehatan Yogyakarta, Yogyakarta, Indonesia

d Universitas Gadjah Mada, Yogyakarta, Indonesia

e President University, West Java, Indonesia
} 


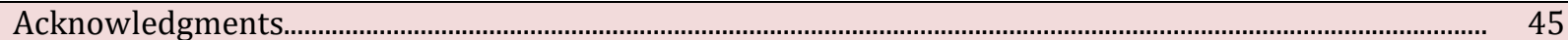

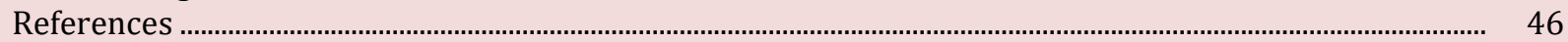

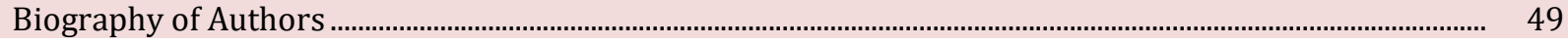

\section{Introduction}

Most experts suggest that when humans blend in with the forest environment, it is perfect for physical and mental health (Weinbrenner et al., 2021). For example, on one day at the weekend, some city people are spending their resting time in the forest or beach, blending with the wild nature, the forest of green trees, free from routine, they do it for the sake of rest and freshness of body and mind after they work hard in the center of the city crowd (Bell \& Wade, 2020). So do not be surprised if the forest has become the habitat of many lives there; it is a source of healthy and natural life (Howden-Chapman et al., 2017). Researchers believe that the forest with green trees is a producer of fresh air needed by all life, both humans and wild animals (Hua et al., 2020). They also said that living in the forest, passing around the forest, such as hiking and other mountain sightseeing activities, is very good for maintaining health and immunity, especially during a pandemic that humans do not want. So to return to nature where avoiding the heat of many people gathering is the right solution (Yousfi et al., 2020). Developed countries with fragile forests tend to organize urban forests to look for places that can be used as protected forests because they are very aware that forests are the source of a healthy life for humans and nature (Lagbas, 2019).

Likewise, the health and environmental experts with their respective arguments have agreed that forests or trees are very good for physical health and also for the mind that comes from the wild, not from nature full of pollution and the hustle and bustle of human life (Haluza et al., 2014). Other studies are also looking for a new understanding that it would be a loss if humans constantly look for crowds to leave the trees and forests. Whereas in the forest actually where the trees, wild animals live. When the sun rises and sets, that is the opportunity for Allah to provide a very healthy and very fresh life for humans and other living creatures (Schaeffer et al., 2012). So, it is not surprising that many health experts associate life in the forest or the trees with treatment and prevention rather than cancer the reason is that; when humans are close to nature, then he will find calm and coolness and breathe fresh air so that their population rises so they can get sick. Nobili et al. (2009), in addition to the forest environment, makes humans cool so they are not easily attacked by stress because according to health experts, the causes of several diseases start from stress, life is like living in a city which is full of busyness and life is so hard, but life in the village or the forest the data is more relaxed and more natural (Grahn et al., 2010).

Living in the forest can help treat calming thoughts and feelings (LI et al., 2010). All humans understand that when they are amid a feeling of relief and pleasure, there must be, even though now humans are increasingly millennial, all technology (Morgan, 2014). However, the sound of nature is very reassuring to the soul and mind where the sun and air on the riverbank and the shade of the trees are a beauty that cannot be rejected by humans (Tuan, 2013; Widana et al., 2021). Moreover, amid a hectic life, humans will look for a convert atmosphere owned by forests and trees, and also green leaves will provide comfort that can reduce stress and worries that are so heavy that they require relaxation and clarity of human thinking (Auden, 2011). So, no one wins anymore; it can heal the mind again, restore energy and vitality, and refresh how we work; it is all related to health in a green forest environment (Shunya, 2017).

On the other hand, humans also understand that immunity will increase when the mood and mind are calmer when the existence of a healthy environment, shady trees will provide more beauty and mystery than nature (Beatley, 2011). This is an advantage of the forest that people sometimes forget. So, one way is to return to the natural forest to get what has been lost from the busyness of human life.

In this exciting review, people living close to trees were found to have better psychological well-being (Donovan \& Prestemon, 2012). Indeed, even the presence of road trees appears to have a positive outcome. One investigation found that areas with more trees had lower stimulant solution velocities. Being near a tree or watching it change with the seasons helps individuals adapt to life in a metropolitan climate, which can be discouraging in itself. It is much better to walk in the forest, but many people have to settle to look at the trees or walk around the neighboring park (Wohlleben, 2016; Santi et al., 2021).

Sembiring, T. B., Maruf, I. R., Susilo, C. B., Hidayatulloh, A. N., \& Bangkara, B. M. A. S. A. (2022). Health literacy study on approaching forest and boosting immune system strategy. International Journal of Health Sciences, 6(1), 40-49. https://doi.org/10.53730/ijhs.v6n1.3145 


\section{Materials and Methods}

This method section describes the procedures and approaches we use when we conduct forest-related health assessments. Many people choose to live in the city center for all the reasons of life. Studies have shown that living close to the forest is healthier and more peaceful than living in the city center. To prove the second assumption above, we first collect study findings that address health and green issues (Ridder, 2014). We target findings from environmental health journals published in the last ten years to make our data accurate and up-to-date. Publications that we visited were Sage, Taylor \& France, Google Books, Academic Publications, and other online material sources (Campbell, 2010). Next, we study and analyze, which involves an in-depth evaluation and coding system to draw conclusions that answer the above problems validly and convincingly. After the study, we report the results in a descriptive qualitative design. All of our data are targeted at secondary data under the phenomenological approach of Guest et al. (2013).

\section{Results and Discussions}

\section{Forest can make the mind work better}

LI et al. (2010), said that anyone would feel more peaceful and happier after walking in the garden trees and also swimming in the sea, everyone will feel the peace of the soul, fresh in breathing because blending with nature is full of play because blending with nature is a gift from God (Coutts, 2016). This is an all-season atmosphere, so the forest still provides something healthy, listening to the body, point but unfortunately, not everyone goes through it, not everyone understands, tends to go through everything they should get back, which is together with nature, close to the trees, all beautiful, all sleeping, all Adam and all listening (Schäffer \& Kistemann, 2012).

Relaxing walks through green forests or other green areas with trees have been found to aid memory and cognition. Protected forest parks and trees have become famous in Indonesia, where humans need green forests. While in countries where forests are hard to find, the thought of the importance of green forests means a lot. Snell et al. (2020), proved that children playing in this forest environment have better intellectual abilities, have better manual fluency, and evaluate hazards better than children raised in confined spaces. The great thing about this outdoor training, whether just for one day, is that children learn about the importance of wood, their considerations, and how they help the planet (Kellert, 2012). A walk in the forest can help lower blood pressure.

Many diseases control and prevention centers in Indonesia, such as clinics and community health centers, promote exercise and national fitness clubs because they realize that the habit of jogging and light exercise blends with the outdoors, and trees such as forests have enormous health benefits (Bangkara et al., 2021). It also ensures that forest workers are welcome to take part. One of the medical benefits in question is that a walk in the forest can help lower the pulse rate. Health professionals asked a small group of volunteers to take a two-hour walk in the included park on the banks of a tree-lined stream (Dounias et al., 2009). As a control, they need to travel relatively in a metropolitan climate. After all, tests were performed, the group had lower pulse rates when walking in the forest area than when walking in the city (Rubinstein, 2015).

\section{Help overweight and back shape}

The relationship between walking in the forest with emotional and physical health through walking and jogging for that study was said by Shunya (2017), discussion about the understanding of what factors help the body to stay healthy, namely through walking and jogging in the yard of the natural environment made by trees and forests. It turns out that data shows that traveling in the trees proves the emotions and moods of those who have a higher frequency of health status than the mood of people who walk in a city full of vehicles and many people (Suparreda, 2020; Dhami et al., 2020). Comfort in body temperature tends to rise because air pollution does not seem to provide better emotional health; in fact, those who jog in parks with trees have 
been shown to show higher physical activity health because they interact with the forest environment (Cakmak et al., 2016).

Studies have found that forests can reduce sadness; many studies have been carried out. Through walks in the forest, humans can get both physical and mental health, significantly reducing depression (Shamshurina et al., 2021). Strolling and exercising in the green and lush wilderness is ideal for managing medical conditions and reducing grief by taking walks with other people. Lee (2016), findings, for example, Korean people often spend time in the Taegyo forest to reduce stress and emotional instability during pregnancy. The exercise program and walks in the Taegyo jungle of Korea are secluded retreats for pregnant couples so that they can experience and experience natural serenity and subtlety. It is also a program to promote a more careful and supportive pregnancy. Program ideas and benefits for pregnancy, children, and other couples are also discussed (Rosa et al., 2020).

\section{Walk for brain activity}

Hasan \& Azis (2018), say that "Shinrin-yoku," or washing the forest (the investment of energy in the forest), is a significant ritual of release. Its effects on psychological health in humans have been investigated. Sixty participants were instructed to walk for 15 minutes through the bamboo forest and metropolitan area (control). Circulatory strain data and electroencephalography (EEG) was used to assess physiological responses; semantic differential strategy (HR) and STAI were used to assess mental reactions. This study indicates that children who invest more energy in forest areas develop better intellectual abilities and prefer manual dexterity than individuals who experience childhood in metropolitan conditions (Song et al., 2015). Therefore, forest kindergartens are becoming increasingly popular in Europe, especially Germany, because they are a straightforward way to start the intellectual transformation of children. Forests play an essential role in life on this planet. Forests cover nearly $33 \%$ of all land on the planet and provide tangible benefits to all species. The air we breathe, the water we drink, everything comes from the forest. Currently, the earth faces environmental changes (environmental change) that can damage life on this planet. The World Bank estimates that by 2030, the impact of environmental change could lead to poverty for 100 million people in the world (Song et al., 2015).

\section{Green trees and immunity booster}

Environmental changes occur due to petroleum derivatives in daily life, such as fuel, coal, and others (AbdelShafy \& Mansour, 2016). As a result of petroleum derivatives, carbon dioxide is distributed significantly, increasing the world's temperature. Thus, the earth faces an extraordinary climate that is difficult to predict. The dry season is getting longer, the air temperature is getting hotter, the ice sheets are melting, sea levels are rising, and there are many more environmental changes that damage life. In this way, hamlets play an essential role in preventing environmental change (Schaeffer et al., 2012). Different trees in the forest can ingest carbon dioxide and deliver oxygen. Forests also function as water catchment areas to prevent flooding. However, as World Wild Life points out, by 2020, forests had lost more than 12 million hectares of hamlet land (Woods \& Naimark, 2020). This is generally what 30 football fields can compare to. Illegal logging, powerless forests practiced by executives, and the transformation of hamlet land into manors added to forest destruction. Various benefits of the forest are beneficial to human endurance. What are the advantages of the hamlet? Understand the conversation below (Damayanti et al., 2018).

Clean air in the forest can hold the carbon dioxide seen around and give off oxygen to provide clean air (Haase, 2017). One mature tree can provide oxygen needs for 2-10 individuals in a day. Fresh air can also cool the earth. Global warming occurs because the release of carbon dioxide continues to expand, making the earth hot. Hot temperatures are causing the polar ice caps to melt, causing sea levels to rise and possibly suffocating waterfront urban areas (Ming et al., 2014). Similarly, hot temperatures can also increase seawater temperatures causing the passage of coral reefs. Coral reefs play an essential role in marine biological systems. With more wood, more carbon dioxide is retained so that temperature increases across the globe can be prevented and cool the earth. Preventing landslides Trees in the forest can prevent landslides because the foundation holds the soil firmly. Forest land can also be a good catchment area because it can absorb abundant water to prevent landslides (Leimona et al., 2015).

Sembiring, T. B., Maruf, I. R., Susilo, C. B., Hidayatulloh, A. N., \& Bangkara, B. M. A. S. A. (2022). Health literacy study on approaching forest and boosting immune system strategy. International Journal of Health Sciences, 6(1), 40-49. https://doi.org/10.53730/ijhs.v6n1.3145 
Prevent flooding and save lives

As water catchment areas, protected forests can also prevent the danger of flooding (Tran et al., 2010). High rainfall is not a problem as long as there is a forest because the forest can assimilate water to the maximum without flooding. Without the forest, water cannot be assimilated, so it quickly overflows, and eventually, floods occur, given that the tropical forest has a confusing biological system. Trees in the forest assimilate water from the soil and channel it into the air and, ultimately, humans to protect health and safety (Wilby \& Keenan, 2012). If the size of the forest is large enough, this condition can affect rainfall. For example, the Amazon rainforest in South America can provide heavy rain to surrounding houses, in any case, which can affect climatic conditions in North America. Give drinking water rainwater that falls in the forest is consumed by different trees, abundant water is not stored in the ground and thrown away. Dirt has several ordinary layers such as stone and sand; this layer can channel water into becoming perfect (Wohlleben, 2016). In this way, some drinking water suppliers take their water supply from the mountains because the mountains have dense forests to clean the water. If there is enough healthy drinking water, then human health can be maintained.

Feeding the forest environment can meet various natural and vegetable needs that meet human food requirements (Antonelli et al., 2020). Many individuals make use of forest lands to develop crops and feed pets. Forests also provide a variety of plants that grow wild and can be used as food. Processed wood springs According to the Central Statistics Agency, forest wood production in 2018 reached more than 50 million cubic meters (Kumar et al., 2020). Forest wood consists of logs, sawn wood, and pressed wood. Forests provide a wide variety of woods used as materials for making furniture, works of art, expressions, and much more. Supporting the economy Forests can be a source of state finance. Processed wood from the hamlet has a vital role in the Indonesian economy (Wijianto et al., 2020). Foreign trade suppliers to foster different areas. Forest and land as initial capital for the advancement of modern manor and training. Ranger's duties in ecological administration if it cannot get close to many people during the Covid pandemic, try visiting the universe. In developed countries, open-air exercises visiting unknown forests, mountains, parks have developed rapidly during the Coronavirus pandemic (Rice et al., 2020). Studies have affirmed the advantages of being in the wild, under tree stands, or visiting a mountain in the natural air. The investigation of Qing Li, who authored the term shinrin-yoku or woodland washing, in the diary National Library of Medicine, tracked down that timberland air produces substances called phytoncides, which assume a part in diminishing pressure by setting off the improvement of normal executioner cells that advance resistance.

\section{Conclusion}

At the end of this health review paper, the author would like to summarize the main content as a helpful learning material for health integration. We repeat that the goal of this kingdom is an effort to seek health with a nature-based approach, an effort to increase the human body's immune system naturally. Through study and evidence from various perspectives or the views of experts, we believe this finding has approached the answer to the question where efforts to post immunity and nature are compared to vaccines and similar drugs, so we believe this is a very natural approach and allows everyone to do it even though not everyone will want and have the understanding. The critical points discussed in the results and discussion sections where we highlight the importance of approaching nature include what can be obtained with the forest approach. The presence of a healthy forest will form a calmer and more intelligent mind.

This is none other than because the natural forest provides oxygen and spiritual information because it is far from the hustle and bustle of human civilization. In other words, humans return to nature, which is very natural given by God and nature. The next point that we offer is that through an approach to the environment such as exercises in parks and forests, this will help return the body from being overweight to an ideal one and reshape a body that is already fat without being cared for ideal. Thus all diseases will be avoided because the body has returned to its ideal. Next, we review how scientific studies evidence says that walking faster is a good activity for brain vitamins where regular body movements give the brain flexibility to form and grow fresher because blood circulation from the heart is pumped to the brain regularly. So we believe this needs to be of concern to all. 
Next, we explain how the green leaves in the forest are the most natural posters to boost the human body's immune system. Life requires healthy food to drink enough and healthy air, undoubtedly giving an extraordinary busker and is only found in green areas, not in the city center. The next point is how we found out from various sources of study where how the forest can also save the human body means here that the forest does give something of its nuance not only giving nature fresh but also approaching the forest is one of the natural things and can prevent from various disasters including floods, landslides. Therefore forests are a gift that needs to be saved and get the attention of many people so that nature has a positive impact on health. That is, among other things, what we describe from the study of forest approaches to increase the immune booster of the human body compared to health and strength such as vaccines and other drugs. We realize that this finding has weaknesses and limitations. Therefore, we are looking forward to suggestions for criticism and improvements to improve and improve the quality of similar studies in the future.

\section{Acknowledgments}

With great pleasure and happiness, we thank all parties who have contributed tremendously in the form of feedback ideas so that this study can be so good and smooth. We also thank the donations that have helped make this study a success. We believe that without the support of all parties, this will not be as reliable as we had planned.

Sembiring, T. B., Maruf, I. R., Susilo, C. B., Hidayatulloh, A. N., \& Bangkara, B. M. A. S. A. (2022). Health literacy study on approaching forest and boosting immune system strategy. International Journal of Health Sciences, 6(1), 40-49. https://doi.org/10.53730/ijhs.v6n1.3145 


\section{References}

Abdel-Shafy, H. I., \& Mansour, M. S. (2016). A review on polycyclic aromatic hydrocarbons: source, environmental impact, effect on human health and remediation. Egyptian journal of petroleum, 25(1), 107123. https://doi.org/10.1016/j.ejpe.2015.03.011

Antonelli, A., Smith, R. J., Fry, C., Simmonds, M. S., Kersey, P. J., Pritchard, H. W., ... \& Qi, Y. D. (2020). State of the World's Plants and Fungi (Doctoral dissertation, Royal Botanic Gardens (Kew); Sfumato Foundation).

Auden, W. H. (2011). The age of anxiety: A baroque eclogue. Princeton University Press.

Bangkara, B. M. A. S. A., Rachmawati, I., Liantoni, F., Hidayatulloh, A. N., \& Suarsa, A. (2021). Optimizing health leadership in early prevention efforts in village communities: Review of public health database. International Journal of Health Sciences, 5(3), 352-363. https://doi.org/10.53730/ijhs.v5n3.1576

Beatley, T. (2011). Biophilic cities: integrating nature into urban design and planning. Island Press.

Bell, V., \& Wade, D. (2020). Mental health of clinical staff working in high-risk epidemic and pandemic health emergencies a rapid review of the evidence and living meta-analysis. Social psychiatry and psychiatric epidemiology, 1-11.

Cakmak, S., Dales, R. E., \& Blanco, C. V. (2016). Does Emotional Health Influence Susceptibility To The Physiologic Effects of Air Pollution On Adults?. International Journal of Sustainable Development and Planning, 11(4), 537-545.

Campbell, H. (2010). When religion meets new media. Routledge.

Coutts, C. (2016). Green infrastructure and public health. Routledge.

Damayanti, A., Tamtomo, D., \& Indarto, D. (2018). Theory of planned behavior implementation on the factors affecting self-care management in type 2 diabetes mellitus patients. Journal of Health Promotion and Behavior, 3(2), 139-145.

Dhami, R. llah M. A.-A., Kadhim, B. M., \& Abdullhusein, H. S. (2020). A serological study to diagnose the causes of recurrent viral and immune miscarriage in aborted women who attend the shatrah general hospital. International Journal of Health \& Medical Sciences, 3(1), 42-47.

Donovan, G. H., \& Prestemon, J. P. (2012). The effect of trees on crime in Portland, Oregon. Environment and behavior, 44(1), 3-30.

Dounias, E., Selzner, A., Kishi, M., Kurniawan, I., \& Siregar, R. (2009). Kembali ke pepohonan hutan? Diet dan kesehatan sebagai indikator respons adaptif terhadap perubahan lingkungan. Pengelolaan sumberdaya hutan di era desentralisasi, 151.

Grahn, P., Tenngart Ivarsson, C., Stigsdotter, U. K., \& Bengtsson, I. L. (2010). Using affordances as a healthpromoting tool in a therapeutic garden. Innovative approaches to researching landscape and health, 1(5), 116-154.

Guest, G., Namey, E. E., \& Mitchell, M. L. (2013). Collecting qualitative data: A field manual for applied research. Sage.

Haase, D. (2017). Urban wetlands and Riparian forests as a nature-based solution for climate change adaptation in cities and their surroundings. In Nature-based solutions to climate change adaptation in urban areas (pp. 111-121). Springer, Cham.

Haluza, D., Schönbauer, R., \& Cervinka, R. (2014). Green perspectives for public health: A narrative review on the physiological effects of experiencing outdoor nature. International journal of environmental research and public health, 11(5), 5445-5461.

Hasan, M., \& Azis, M. (2018). Pembangunan Ekonomi \& Pemberdayaan Masyarakat: Strategi Pembangunan Manusia dalam Perspektif Ekonomi Lokal.

Howden-Chapman, P., Siri, J., Chisholm, E., Chapman, R., Doll, C. N., \& Capon, A. (2017). SDG 3: Ensure healthy lives and promote wellbeing for all at all ages. A guide to SDG interactions: from science to implementation. Paris, France: International Council for Science, 81-126.

Hua, L., Xiaoyi, C., Runping, N., \& Yuhai, S. (2020). Analysis of the Influence of Green Building Fresh Air System on Indoor Environment Based on Improved Analytic Hierarchy Process. In IOP Conference Series: Earth and Environmental Science (Vol. 546, No. 3, p. 032024). IOP Publishing.

Kellert, S. R. (2012). Building for life: Designing and understanding the human-nature connection. Island press.

Kumar, A., Adamopoulos, S., Jones, D., \& Amiandamhen, S. O. (2020). Forest biomass availability and utilization potential in Sweden: A review. Waste and Biomass Valorization, 1-16. 
Lagbas, A. J. (2019). Social valuation of regulating and cultural ecosystem services of Arroceros Forest Park: A man-made forest in the city of Manila, Philippines. Journal of Urban Management, 8(1), 159-177. https://doi.org/10.1016/j.jum.2018.09.002

Lee, L. (2016). Autonomous learning through task-based instruction in fully online language courses. Language Learning \& Technology, 20(2), 81-97.

Leimona, B., Lusiana, B., van Noordwijk, M., Mulyoutami, E., Ekadinata, A., \& Amaruzaman, S. (2015). Boundary work: Knowledge co-production for negotiating payment for watershed services in Indonesia. Ecosystem services, 15, 45-62. https://doi.org/10.1016/j.ecoser.2015.07.002

LI, C. J., JIANG, S. Y., \& ZHU, H. M. (2010). Study of Protecting and Developing Geographical Indication of Agricultural Products in the Industrialization. Journal of Hefei University (Social Sciences), 03.

Ming, T., Liu, W., \& Caillol, S. (2014). Fighting global warming by climate engineering: Is the Earth radiation management and the solar radiation management any option for fighting climate change?. Renewable and Sustainable Energy Reviews, 31, 792-834. https://doi.org/10.1016/j.rser.2013.12.032

Morgan, J. (2014). The future of work: Attract new talent, build better leaders, and create a competitive organization. John Wiley \& Sons.

Nobili, S., Lippi, D., Witort, E., Donnini, M., Bausi, L., Mini, E., \& Capaccioli, S. (2009). Natural compounds for cancer treatment and prevention. Pharmacological research, 59(6), 365-378. https://doi.org/10.1016/j.phrs.2009.01.017

Rice, W. L., Mateer, T. J., Reigner, N., Newman, P., Lawhon, B., \& Taff, B. D. (2020). Changes in recreational behaviors of outdoor enthusiasts during the COVID-19 pandemic: analysis across urban and rural communities. Journal of Urban Ecology, 6(1), juaa020.

Ridder, H. G. (2014). Book Review: Qualitative data analysis. A methods sourcebook.

Rosa, C. D., Larson, L. R., Collado, S., \& Profice, C. C. (2020). Forest therapy can prevent and treat depression: evidence from meta-analyses. Urban Forestry \& Urban Greening, 126943. https://doi.org/10.1016/j.ufug.2020.126943

Rubinstein, D. (2015). Born to walk: The transformative power of a pedestrian act. ECW Press.

Santi, L. K. S., Sudewi, A. A. R., Duarsa, D. P., \& Lesmana, C. B. J. (2021). The effect of pregnancy massage on level of depression, anxiety and stress in pregnant women. International Journal of Health \& Medical Sciences, 4(2), 220-225.

Schaeffer, R., Szklo, A. S., de Lucena, A. F. P., Borba, B. S. M. C., Nogueira, L. P. P., Fleming, F. P., ... \& Boulahya, M. S. (2012). Energy sector vulnerability to climate change: a review. Energy, 38(1), 1-12. https://doi.org/10.1016/j.energy.2011.11.056

Schäffer, S. D., \& Kistemann, T. (2012). German forest kindergartens: Healthy childcare under the leafy canopy. Children Youth and Environments, 22(1), 270-279.

Shamshurina, N. G., Shamshurin, V. I., Laamarti, Y. A., Ryabchikova, L. N., Nikolaev, A. A., \& Peremibeda, P. A. (2021). Public administration strategy of healthcare system for seniors. International Journal of Health Sciences, 5(3), 630-638. https://doi.org/10.53730/ijhs.v5n3.2720

Shunya, A. (2017). Ayurveda lifestyle wisdom: A complete prescription to optimize your health, prevent disease, and live with vitality and joy. Sounds True.

Snell, T. L., Simmonds, J. G., \& Klein, L. M. (2020). Exploring the impact of contact with nature in childhood on

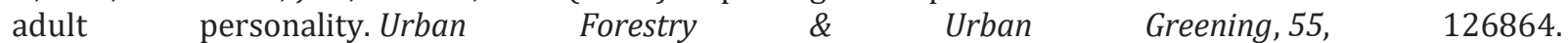
https://doi.org/10.1016/j.ufug.2020.126864

Song, C., Ikei, H., Kobayashi, M., Miura, T., Taue, M., Kagawa, T., ... \& Miyazaki, Y. (2015). Effect of forest walking on autonomic nervous system activity in middle-aged hypertensive individuals: A pilot study. International journal of environmental research and public health, 12(3), 2687-2699.

Suparreda, S. B. (2020). Redesain Taman Rekreasi Wonderi dikota Semarang (Doctoral dissertation, Universitas 17 agustus 1945 Surabaya).

Tran, P., Marincioni, F., \& Shaw, R. (2010). Catastrophic flood and forest cover change in the Huong river basin, central Viet Nam: A gap between common perceptions and facts. Journal of Environmental Management, 91(11), 2186-2200. https://doi.org/10.1016/j.jenvman.2010.05.020

Tuan, Y. F. (2013). Romantic geography: in search of the sublime landscape. University of Wisconsin Pres.

Sembiring, T. B., Maruf, I. R., Susilo, C. B., Hidayatulloh, A. N., \& Bangkara, B. M. A. S. A. (2022). Health literacy study on approaching forest and boosting immune system strategy. International Journal of Health Sciences, 6(1), 40-49. https://doi.org/10.53730/ijhs.v6n1.3145 
Weinbrenner, H., Breithut, J., Hebermehl, W., Kaufmann, A., Klinger, T., Palm, T., \& Wirth, K. (2021). "The Forest Has Become Our New Living Room"-The Critical Importance of Urban Forests during the COVID-19 Pandemic. Frontiers in Forests and Global Change, 4, 68.

Widana, I.K., Sumetri, N.W., Sutapa, I.K., Suryasa, W. (2021). Anthropometric measures for better cardiovascular and musculoskeletal health. Computer Applications in Engineering Education, 29(3), 550561. https://doi.org/10.1002/cae.22202

Wijianto, W., Cahyono, D., \& Qomariah, N. (2020). How to Improve Employee Performance at the Forest Service. International Journal of Scientific \& Technology Research, 9.

Wilby, R. L., \& Keenan, R. (2012). Adapting to flood risk under climate change. Progress in physical geography, 36(3), 348-378.

Wohlleben, P. (2016). The hidden life of trees: What they feel, how they communicate-Discoveries from a secret world (Vol. 1). Greystone Books.

Woods, K. M., \& Naimark, J. (2020). Conservation as counterinsurgency: A case of ceasefire in a rebel forest in southeast Myanmar. Political Geography, 83, 102251. https://doi.org/10.1016/j.polgeo.2020.102251

Yousfi, N., Bragazzi, N. L., Briki, W., Zmijewski, P., \& Chamari, K. (2020). The COVID-19 pandemic: how to maintain a healthy immune system during the lockdown-a multidisciplinary approach with special focus on athletes. Biology of sport, 37(3), 211. 


\section{Biography of Authors}

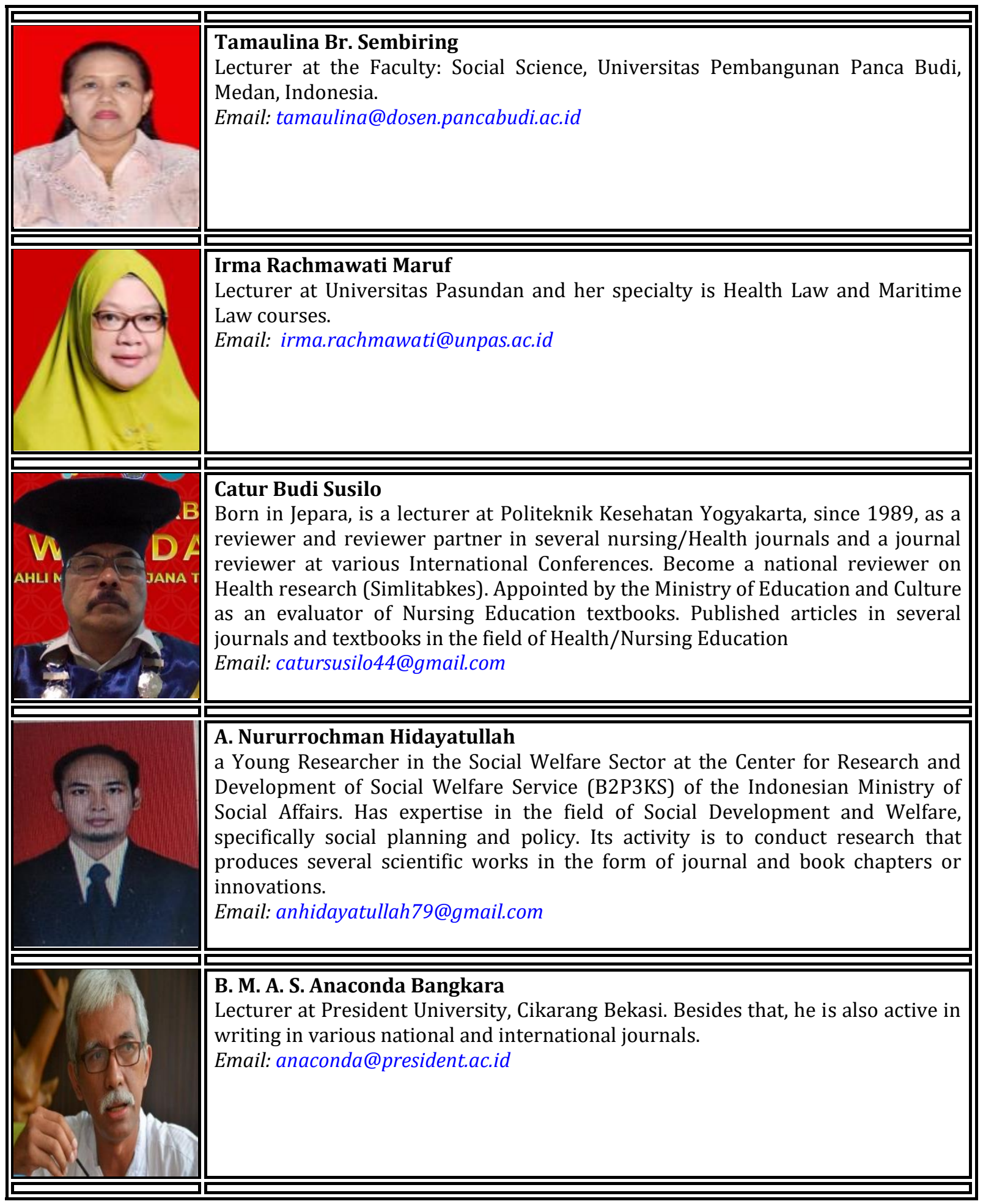

Sembiring, T. B., Maruf, I. R., Susilo, C. B., Hidayatulloh, A. N., \& Bangkara, B. M. A. S. A. (2022). Health literacy study on approaching forest and boosting immune system strategy. International Journal of Health Sciences, 6(1), 40-49. https://doi.org/10.53730/ijhs.v6n1.3145 